\title{
From the editors
}

We are pleased to introduce the second issue of the re-launched Journal of Public Policy with a new interior design. The interior of the journal now also has a new look. The articles in this issue address important topics in the administrative side of the public policy-making process. What is more, the essays blend themes in public management and policy to develop new theory as well as providing evocative empirical findings.

In the lead article, George Krause provides a formal theory addresses political and administrative agency problems in a unified way. "Representative Democracy and Policymaking in the Administrative State: Is Agency Policymaking Necessarily Better?" provides novel claims about the way in which informational and distributional benefits of administrative delegation serve voter interests. The next essay, "Moving In, Managing Up: Executive Job Formation and Political Behavior" by Manuel Teodoro applies examines a theory inspired by personnel economics in data sets capturing the management practices of police chiefs, school superintendents and water utility matters, finding that officials hired from outside their agencies have more interaction with their political superiors. Teodoro's essay provides provocative evidence that career trajectories have an impact on both the policy process and democratic performance. Markus Tepe and Pieter Vanhuysse relate public personnel processes to electoral politics in "Cops for Hire? The Political Economy of Police Employment in the German States". In the context of German länder, uncover an interesting relationship between police hiring and the political business, showing evidence that more police are hired in anticipation of elections and by conservative party incumbents. In a stimulating essay entitled "Governance and Organizational Effectiveness: Toward a Theory of Government Performance" by Laurence Lynn and Robbie Waters Robichau argue that the role of formal hierarchies in administrative organisation is more important in understanding the effectiveness of public management than scholars have more recently believed by summarising information from a wide variety of studies. Finally, in "Public Sector Reform and Blame Avoidance Effects", Peter Mortensen leverages a hospital reform in Norway that took place in 2002 to find 
empirical evidence that the attribution of blame or credit by media outlets shifts when administrative authority in a policy area is altered.

Taken together, the papers in this issue provide interesting new insights into the management of public policies. It is worth noting that this is not a special issue, but, rather, a collection of papers independently submitted that serve as a testament to the robust scholarly interest in the role of administration in the policy process. We hope you will find them stimulating.

Anthony Bertelli

Peter John 